\title{
LEGACY OF THE TRIAD:
}

\section{ARCHITECTURE IN MEDIEVAL SERBIA BETWEEN STYLE AND IDEOLOGY IN THE WORK OF ALEKSANDAR DEROKO}

\author{
A B S S T R A C T
}

Despite criticism that has been leveled against Gabriel Millet's well-known tripartite subdivision of architecture of medieval Serbia into three distinct 'schools', its scholarly authority still remains largely unchallenged. Yet what is believed to have stemmed from Millet's ingenious research was inextricably linked with the ideological project of Serbian national emancipation during the first decades of the twentieth century. His stylistic triad of L'école de Rascie, L'école de la Serbie byzantine and L'école de la Morava had an unexpectedly vivid and profound afterlife in the entirely new context of socialist Yugoslavia - in terms of both scholarship and ideological resonance. Its main proponent was Serbian architectural historian Aleksandar Deroko, whose book entitled Monumental and Decorative Architecture in Medieval Serbia apparently only reiterated the existing subdivision of medieval architecture by simply changing the word 'schools' into 'groups'. Nevertheless, a closer look at three successive editions of the book published in 1953, 1962 and 1985 reveals a series of Deroko's encounters with the Milletian framework, suggesting that his enterprise can be seen as instrumental to the ideological re-appropriation of medieval heritage in the context of the national question in Yugoslavia.

\footnotetext{
Aleksandar Ignjatović

University of Belgrade - Faculty of Architecture

aleksandar.i@arh.bg.ac.rs
}

KEY WORDS

MEDIEVAL ARCHITECTURE

MEDIEVAL SERBIA

NATIONAL IDENTITY

NATIONALISM

IDEOLOGY

POLITICS 
There was hardly any Serbian author of the twentieth century whose work in the field of medieval architecture was so versatile as to shift from scholarly studies to suggestive drawings, from minor questions to comprehensive treatises, as that of Aleksandar Deroko's. Although he was a keen draughtsman as well as a high-spirited writer and somewhat deliberately unpretentious painter, Deroko is primarily remembered as a polyhistor of sorts. ${ }^{1}$ However, his work was characterised by common themes and conventional interpretation. Seen from today's perspective, his profile as a medievalist is more of a systematiser and compiler than a pioneering researcher. Despite his arguable contribution to scholarship, Deroko's Monumental and Decorative Architecture of Medieval Serbia (Monumentalna i dekorativna arhitektura u srednjovekovnoj Srbiji) has been the sole monograph on the subject written since the mid-twentieth century. The book has been an educational basis not only for architecture and art history students, but also for connoisseurs of medieval culture as well as a wider readership. ${ }^{2}$ Full of illustrations and photographs which outweigh the text, it has become an instrument of visual literacy in the field of Serbian medieval studies. Initially published in 1953 as a university textbook, it had two more editions (1962, 1985), both of poorer quality compared to the first edition. There were insignificant alterations in certain chapters and some minor changes, but the main body of the text remained unchanged in all three editions. ${ }^{3}$ (Fig. 1)

Despite a widespread perception that Monumental and Decorative Architecture is a 'still incomparable" 4 piece of scholarship because it evidently represents an 'exceptional effort which would need a whole team of researchers to produce', 5 the book heavily relied on the work of the French archaeologist and art historian Gabriel Millet (1867-1953). More particularly, Deroko appropriated Millet's well-known interpretive scheme by which architecture in medieval Serbia could be subdivided into trois écoles bien distinctes. Initially drafted in 1917 and published two years later in a monograph called L'ancien art serbe: les églises, Millet's scheme delineated church architecture in medieval Serbia into three 'schools' based on the criteria of typology and style: L'école de Rascie (The Raška School), L'école de la Serbie byzantine (The School of Byzantinized Serbia) and L'école de la Morava (The Morava School). ${ }^{6}$ In the following decades, this tripartite scheme acquired a status of high scholarly standard, eventually becoming a bastion of sacrosanctity among Serbian architectural historians. Nevertheless, Millet simultaneously resolved the problem of stylistic heterogeneity of architecture in medieval Serbia and left a heavy burden on the shoulders of Serbian historians who still have not seriously challenged the scheme's basic premises. ${ }^{7}$ Most of them have been reluctant to call into question the very idea of 'national causes in architectural studies' championed by the 


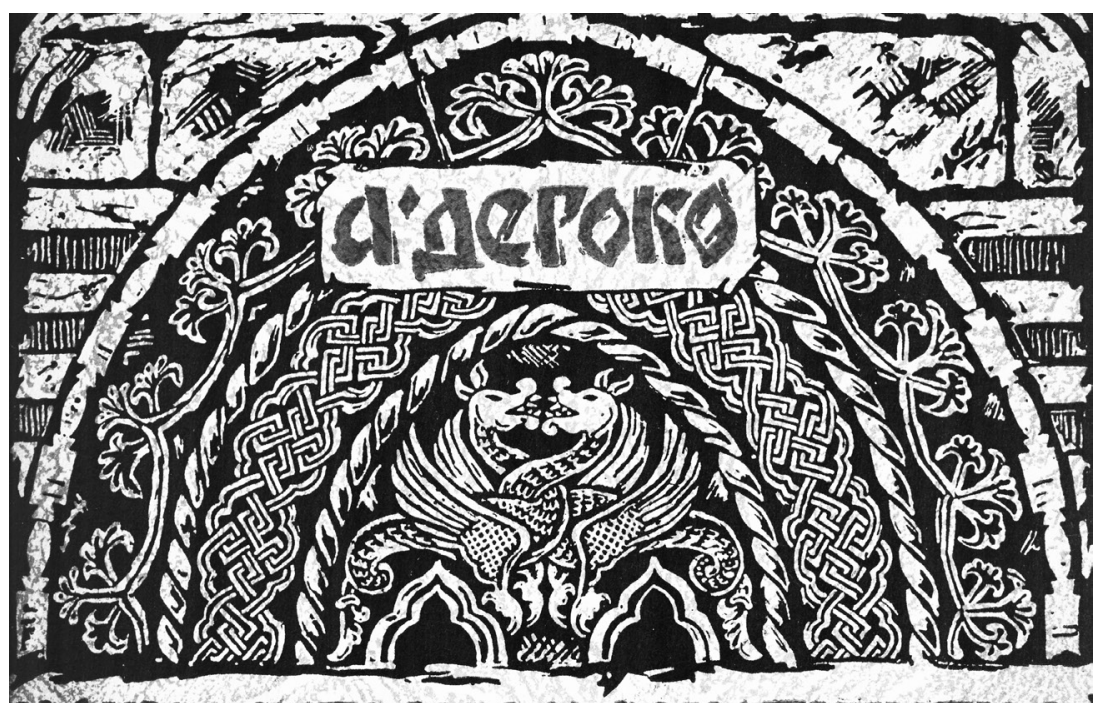
MonyewTanha M Jersoramuiba MPUTCRIDP

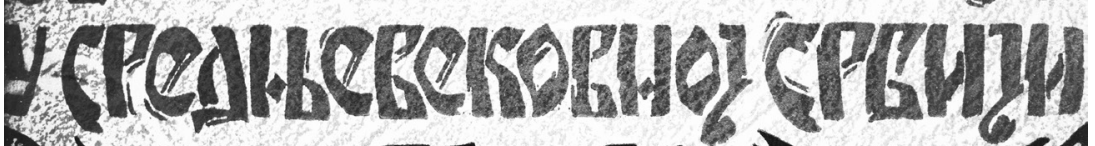

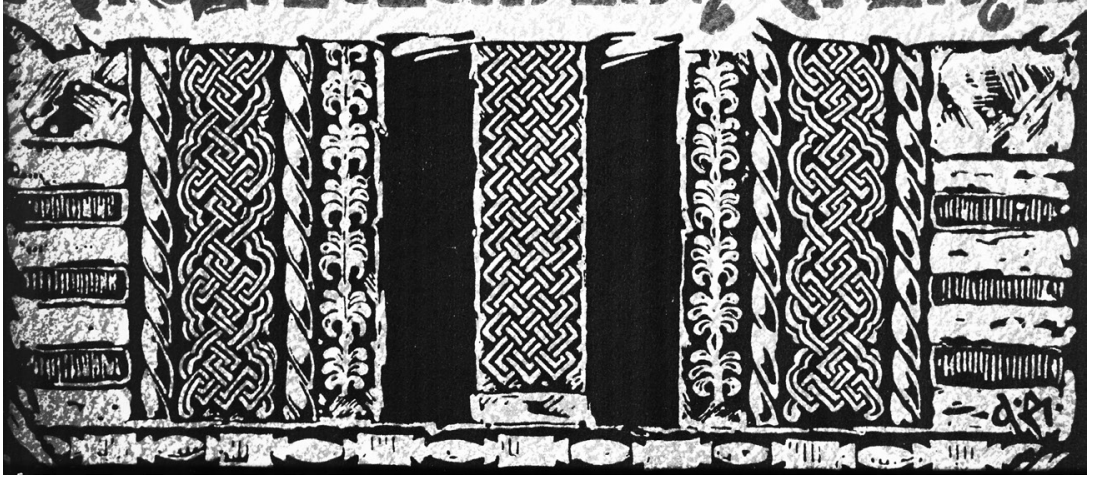

Fig. 1. Book cover of Monumental and Decorative Architecture in Medieval Serbia (1953) by Aleksandar Deroko. 
French scholar, ${ }^{8}$ whose work resonated the romantic idea of national spirit embodied in cultural products. More particularly, in the interwar period Millet's interpretation and its numerous ramifications became not only associated with a dubious idea of national spirit in the Middle Ages, but were impregnated with nationalist connotations. ${ }^{9}$

A considerable merit of Deroko's book lies in the fact that it firmly re-established and popularised Millet's theory when an older, pre-WWII historiographical tradition faced the challenge of accommodating itself to quite a new ideological milieu of socialist Yugoslavia. In the opening chapter of his book, Deroko praised Millet's work for its sheer amplitude, ${ }^{10}$ modestly omitting his own encounters with the French scholar with whom he had studied decades before, spending a semester at the École Pratique des Hautes Études in 1926. ${ }^{11}$ There is no doubt that Monumental and Decorative Architecture - published inadvertently in the year of Millet's death - was a direct intellectual offshoot of L'ancien art serbe, still cherished by many Serbian ${ }^{12}$ and foreign scholars. ${ }^{13}$ 'Owing to the combined legacy of Millet's book, followed by the one by Deroko, we can conclude that for three successive generations the notions expressed by the French scholar, as Slobodan Ćurčić has put it, "have informed the manner of looking at and the thinking about the medieval architectural heritage of Serbia'. ${ }^{14}$ As one of Deroko's biographers emphasises, Millet's book has 'left the door ajar so that he could see the hidden treasures of Serbian art as well as the splendour of the Byzantine'. ${ }^{15}$ Nevertheless, in his introduction Deroko underlined the fact that Millet was not his sole source, praising the Russian scholar Pyotr Pokryshkin (1870-1922), among other historians, who had greatly contributed to the study of architecture in medieval Serbia. ${ }^{16}$

Contrary to Millet's interpretation raised by Serbian scholars, ${ }^{17}$ Deroko never passed judgement on the interpretive triad of the French master, apart from minor rhetorical claims published prior to Monumental and Decorative Architecture in $1950 .{ }^{18}$ Even after the publication of the book three years later, he continued to cast a mildly critical eye on Millet's classical enterprise but without a clear idea as to how it might be revised and improved. ${ }^{19}$ In fact, Deroko only partially modified Millet's architectural types calling them 'groups' instead of 'schools' ${ }^{20}$ He largely ignored the problem of dissimilitude between architectural style and chronology in Millet's tripartite scheme, relying almost exclusively on stylistic criteria for development of architecture despite having underlined the importance of political and economic factors in the introduction. ${ }^{21}$ Yet despite the flaws in Deroko's arguments, as well as a curious fact that a university textbook served as 'the standard work on the 
subject also [and even] in scholarly contexts', ${ }^{22}$ the position of Monumental and Decorative Architecture within the social context of socialist Yugoslavia was tremendously indicative of the ideological and political roles of architectural history. Both the appropriation and modification of the original Millet's scheme, so evident in Deroko's book, far surpassed the epistemological boundaries of the contemporaneous Serbian history of architecture. Several of his deserve great attention in this respect, including Medieval Towns and Castles in Serbia, Montenegro and Macedonia (Srednjovekovni gradovi u Srbiji, Crnoj Gori i Makedoniji, 1950), Architectural Monuments from the Ninth to Eighteenth Century in Yugoslavia (Spomenici arhitekture IX-XVIII veka u Jugoslaviji, 1964), ${ }^{23}$ and With Ancient Master Builders: Medieval Monasteries in Serbia, Montenegro and Macedonia (Sa starim neimarima: Srednjovekovni manastiri u Srbiji, Crnoj Gori i Makedoniji, 1967). ${ }^{24}$ But it was his master work on medieval architecture that, if contextualised and critically examined, can reveal some of the underlying reasons for the seemingly inexplicable afterlife of the Serbian-centred interpretation in an apparently non-nationalistic milieu of new Yugoslavia. Seen through the dual prism of mainstream historiography and the central tenets of the country's official doctrine of 'brotherhood and unity' which simultaneously advocated the Yugoslav nations' unity and diversity Deroko's ambiguous stance towards Millet appears to be less erratic and more ideologically instrumental.

The question is whether Deroko appropriated the otherwise problematic tripartite scheme because of high regard for Millet - who remains highly praised by Serbian scholarship to this day ${ }^{25}$ - or because the reasons for the unexpected afterlife of the Milletian interpretation may have been much more complex. It is hard to believe that the sole reason for Millet's survival in the new scholarly context was the mastery of his interpretation; and it certainly was not only historiographical inertia, common among Serbian architectural historians, which kept an obsolete scheme relevant half a century after it had been created. It is rather that the older, Serbian-centred Milletian tradition of interpreting medieval heritage, heralded by Millet and upheld by other post-war Serbian authors such as Đurđe Bošković (1904-1990), which was in tune with the general concern about the 'national question', the most central, neuralgic issue of the political and social life of socialist Yugoslavia. More particularly, Monumental and Decorative Architecture represented a sprout of the old, late nineteenth-century tradition of imagining Serbian national unity, which was reintroduced in the new context as an integral part of a much wider disputative discourse about the national question in Yugoslavia and its basic principle of federalisation. 
The basic argument of this paper is that architecture in medieval Serbia, as described and systematised by Deroko, represented much more than the vestiges of a bygone era - a stance that was quite contrary to his own assessments of the need for dissociating artworks and their creators from their social and political milieu. ${ }^{26}$ The point of departure is that the heritage of medieval Serbia became a knowledge-system of great ideological importance, by which architectural historians used a pre-national medieval past not only to legitimise, but also to problematise the Serbian national question in socialist Yugoslavia. One can comprehend Deroko's written endeavours in their own epistemological and political context not as mere university course books, whose scope and structure were apparently drawn from the hitherto common historical interpretations. They were, in fact, part of the 'selective reactivation' of historical and interpretive legacies on the part of Serbian elites in Yugoslavia, preoccupied with the issue of the federalisation of the state and its effect on Serbs. ${ }^{27}$ It was in that sense that Deroko's reactivation of Millet's theses did not reflect scholarly conformism and historiographical inertia, but constituted part of a wider discourse of the Serbian national question in a dynamic and constantly changing political reality of socialist Yugoslavia. In the context sharply marked by an ever-increasing degree of federalisation, which caused that the country's largest nation became distributed across a number of republics and autonomous provinces, the historicisation of the unity of the Serbian nation had some important implications. To understand the ideological power of Deroko's interpretation beyond his predecessor's L'ancien art serbe would be equal to understanding the Serbian national question in socialist Yugoslavia without acknowledging the formative periods of Serbian nationalism.

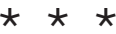

Deroko's writings should be considered in a broader framework of heightened interest for medieval history in post-WWII Yugoslavia, which became more acute after the Imformbureau Resolution of 1948, when the establishment broke its close bonds with the Soviet Union and ventured into constructing a particularly Yugoslav master narrative. This narrative would be based on the historicization of the Yugoslav nations' 'brotherhood and unity', which historians duly projected on the deep medieval past. Over the course of the 1950s and 1960s, the country's medieval cultural heritage was critically reinterpreted along two distinct lines - one concerned with each nation's particular identity, the other with their historical encounters and interconnections. ${ }^{28}$ Contrary to the integralist, pre-WWII Yugoslav idea, the new narrative insisted on separate histories and identities of all national groups in the country, which were 
interpreted as being connected by common historical interests and ideals, and not necessarily by ethnic ties. One of the earliest and most typical examples of this heightened and peculiar interest in the Yugoslav Middle Ages was the great Exhibition of Medieval Art of the Yugoslav Peoples held in Paris in 1950. Accompanied by a catalogue written by Miroslav Krleža, the Croatian novelist and a prominent figure of the establishment, the exhibition presented the rich and diverse medieval heritage of Yugoslavia as multicultural and multi-ethnic, but also complementary in a way analogous to the cultural imagination of 'brotherhood and unity'.

Nonetheless, the reasons for the permanent presence of the medieval past in the Yugoslav master narrative were much more complex. Firstly, the history of the Middle Ages represented a cornerstone for conceiving the Yugoslav peoples as historical subjects, their origins and evolution, as well as their mutual relationships. This included both pre-WWII constitutional nations (i.e. Serbs, Croats, Slovenes), which in the new context needed new forms of historical legitimacy, as well as newly-recognised national groups - such as Macedonians and Montenegrins, along with Bosnian Muslims, which were regarded as nations by the federal constitutions of 1946 and 1963 respectively. They all required ideologically suitable status and cultural authenticity rooted in history. Their 'national' pasts became integral not only to the discursive production of the shared revolutionary traditions of the Yugoslav peoples and to their mediatory identities - in terms of both politics and culture - which suited the country's non-alignment policy in the Cold War World. ${ }^{29}$ Above anything else, the historicization of the Yugoslav nations corresponded to the process of political federalisation, accomplished in the ambiguous ideological framework of 'brotherhood and unity', which referred simultaneously to the fundamental closeness and inherent differences between the country's ethnic groups. It was in this discursive process that the history of South Slavs, their separation into different ethnic camps and their early medieval state formations acquired great ideological significance. Frequently cited words by Krleža about the importance of medieval history for the Yugoslav people's self-perception is perhaps the best evidence of these ideological assets. 'The socialist anticipation of today', he wrote in 1949, 'is but a correlate of a whole series of our South Slavic medieval anticipations; of the old Slavonic, Glagolitic and autocephalic battle for the equality of nations and languages; in the church hierarchies of Greco-Latin Caesaropapism and imperialism'. ${ }^{30}$ On another occasion, Krleža wrote that 'our Middle Ages, due to their ethical, political and cultural elements, anticipate the course of our future centuries'. ${ }^{31}$ What stood behind these thoughts was that the plurality of medieval pasts (not the idea of a single, 
primordial unity of the peoples) as well as a dialectic relationship between history and the future within the temporal totality of Yugoslavs that the new, post-1948 historiography started to accomplish. A basic, trans-temporal force that linked the histories and identities of various Yugoslav peoples was believed to be cultural self-awareness, distinctive but complementary ethnic cultures, as well as a vehement resistance to 'foreign' influences. These were some of the principal ideas which steered the production of different medieval 'national' histories in post-war Yugoslavia.

Deroko's writings on medieval architecture should be considered not only in this historiographical environment of heightened ideological awareness of the Middle Ages but also in respect of the Marxist paradigm of history, which in many ways corresponded with the theoretical and epistemological basis of the humanities in socialist Yugoslavia. Despite the fact that the orthodox, Soviet-style vulgarisation of Marxism was continually castigated in Yugoslav historiography, ${ }^{32}$ some of its basic teleological claims remained even after 1948. ${ }^{33}$ For example, Deroko's Monumental and Decorative Architecture, along with his other books on the subject, was firmly entrenched in the classical Marxist credo of the inevitability of progress in history. His interpretation of medieval architecture relied on the idea that the historical development of the society, its economic foundations and cultural production are highly interdependent. For Deroko, architecture in medieval Serbia should be seen in a dual perspective of an economic base and ideological superstructure. ${ }^{34}$ 'The economic interests of the ruling classes were opposed to those of common people', wrote Deroko, in line with the Marxist historiography's interest for economic force, ${ }^{35}$ while the Serbian Orthodox Church represented a 'bold weapon of the ruler [...] with whom it shared many mutual interests' ${ }^{36}$ Moreover, he grasped the basic framework of historical materialism about various forms of state having 'their roots in the material conditions of life'. ${ }^{37}$ This is best seen when Deroko touches upon South Slavs' class differentiation, capital accumulation and increased concentration of power in the period between the sixth and ninth centuries, which were processes leading to new forms of social organisation and, eventually, modern-day nations.

Deroko's accounts about medieval rulers having both significant material resources and ideological motives for constructing great churches fit into a wider scheme of historical materialism with its base/infrastructure thesis, which heavily influenced Yugoslav historiography at the time of the first edition of Monumental and Decorative Architecture. ${ }^{38}$ The pioneering and most important synthetic study on medieval history in Yugoslavia entitled A History 
of the Yugoslav peoples, ${ }^{39}$ which was outlined by its multi-national editorial staff as the "first comprehensive effort to interpret our past on the basis of historical materialism' ${ }^{40}$ subsequently became a standard against which many art and architectural histories were written. Nevertheless, the effect of Marxist orthodoxy 'on historiography proved uneven [so that] scholars of the Byzantine, medieval and Ottoman periods', unlike historians concerned with modern history, 'did not feel constrained in their studies to make major concessions to Marxist schemes of history'. ${ }^{41}$ Indeed, not only Deroko but also other Serbian architectural historians paid more attention to the question of form, typology and, above all, national styles than to economic and class structures that underpinned architecture. Ironically, Monumental and Decorative Architecture indicates 'the supremacy of national history over the Marxist global outlook' that distinguished mainstream historiography in socialist states..$^{42}$

On the other hand, Deroko's narratives were closely tied to the predominant theoretical paradigm of Yugoslav art history, archaeology and anthropology, which conceptualised ethnic or national groups as culturally confined and distinctive. The nations were seen as more or less culturally coherent historical subjects, clearly differentiated by their distinctive cultures. However, the identification of medieval ethnic groups with the nations of contemporary Yugoslavia was more problematic and less straightforward than one may have expected. For example, while Deroko was talking about peoples in medieval Serbia, he was confidently using the ethnonyms 'Serbs' and 'Croats', while at the same time being reluctant to identify the historical communities of Macedonia and Montenegro as the antecedents of modern-day Macedonians and Montenegrins. This ambiguous policy of identity contributed to the dynamics of Deroko's narrative, while at the same time producing anxiety about the historical foundations of the country's ethnic groups. This was the case with the entire medieval studies in Yugoslavia, which were characterised by the negotiation of different concepts of collective identity and sharply marked by the historicisation of nations and nationalities. ${ }^{43}$ More particularly, the conceptual framework of the humanities in Yugoslavia was the so-called cultural-historical method, characterised by the belief in an authentic national culture and the idea of cultural autochthony. ${ }^{44}$ 'The cultural-historical method' presupposes that human societies of the past were homogenous and 'confined in strictly limited areas, which were governed by the same cultural norms expressed in both material culture and language'. ${ }^{45}$ For Deroko, medieval Serbs represented a culturally articulated community occupying a clearly differentiated territory. This presupposed that they were distinguished by the congruence of ethnic identity, political boundaries and cultural forms - like those of Millet's architectural types. 
In Deroko's book, Serbian historical homelands overlapped with the socialist republics of Serbia, Macedonia and Montenegro, as well as parts of Croatia and the autonomous province of Kosovo, which was clearly noticeable on numerous hand-drawn maps accompanying the text. (Fig. 2) These graphic representations of national historicity created a tension between two distinctly different phases in Serbian history. As a matter of fact, this was a dichotomy between historical rights and ethno-linguistically based national sovereignty, which otherwise permeated Monumental and Decorative Architecture in its obligatory and conflicting references to both modern-day republics and medieval territories. Deroko's book mirrored a key ideological conundrum of socialist Yugoslavia about the legitimacy of federalisation sanctioned by a confusing and unprincipled blend of historical and ethnic criteria. The fact that the 'members of a nation were not restricted to the republic in which the nationality predominated' while, at the same time, 'each republic was considered a nation-state in the sense that is served as a rough equivalent of the homeland of the dominant nationality within its boundaries', ${ }^{46}$ was a principal feature of the ideological context in which Deroko's written and graphic narratives operated as a critical discourse about the nation. His seemingly innocuous politics of identity, marked by the dialectic relationship between different ethnic epithets referring to both ancient and contemporary peoples, was in fact segregating Yugoslav nations according to their historical status. The simultaneous use of the different pairing of ethnonyms such as 'Serbian' / 'Slavic', 'Croatian', 'Macedonian-Slavic', 'Doclean' (but not 'Macedonian' or 'Montenegrin'), was part of a wider critical response to the federalist composition of socialist Yugoslavia and the identity of the state ethnic groups in history. Truly, Deroko's politics of identity was based on architecture as a discursive tool for challenging the foundations and limits of national and territorial sovereignty. By associating the political formation of medieval Serbia with its supposedly Serbian national character, he questioned the historical foundation of the nations living on 'someone else's' historical homelands.

Monumental and Decorative Architecture was deeply anchored in national determinism, which not only promoted the idea that the ideal habitus of a nation is a national state, but also that architecture was an expression of the "national spirit'. This was an old, nineteenth-century concept that became prominent in the context of providing historical legitimacy for the Yugoslav federalisation. In line with this historiographical trend, Deroko appropriated Millet's idea of a single and common, Serbian national spirit permeating all three sub-national schools of medieval architecture. ${ }^{47}$ For him, the most fundamental feature of this Serbian spirit was 'originality', a feature that had preoccupied Serbian art 


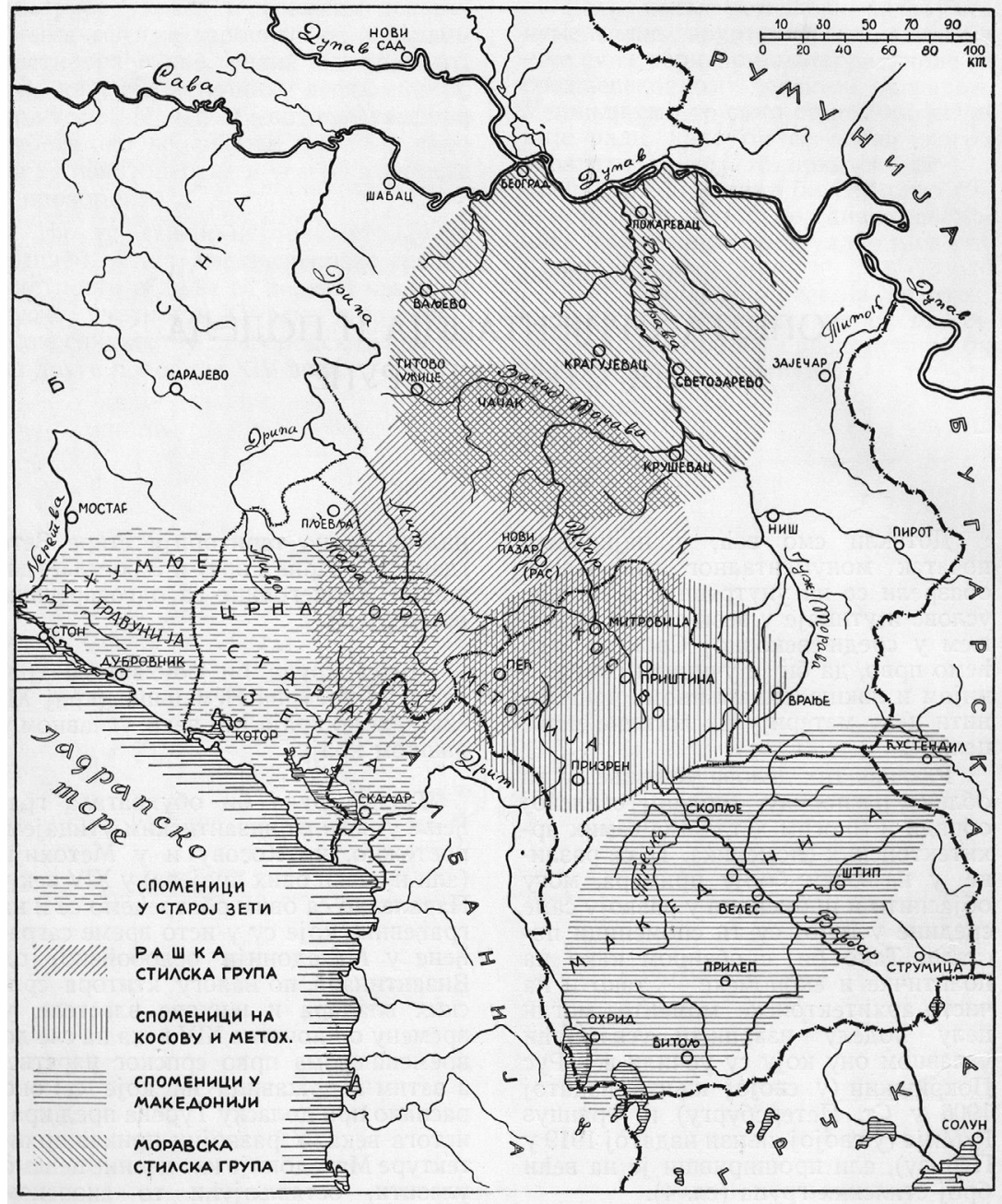

Fig. 2. A. Deroko's map showing distribution of architecture in medieval Serbia, Zeta and fourteenthcentury Macedonia. (Source: Aleksandar - A. Deroko, Monumentalna i dekorativna arhitektura u srednjovekovnoj Srbiji (Belgrade: Naučna knjiga, 1953), 24.) 
and architectural historians since the discipline's formative days in the latenineteenth century. The question of national culture and the cult of authenticity and originality were closely tied to the interpretation of Serbian ethnogenesis as well as the historiographical mythologisation of medieval Serbia's political autochthony. ${ }^{48}$ Like many other Serbian authors writing on architecture in medieval Serbia, Deroko praised its national character which stemmed from an autochthonous Serbian spirit, as well as the peculiarly Serbian adaptation of 'foreign influences' coming from both East and West. Actually, Deroko turned back to an older interpretive tradition based on duality of autochthonous and foreign, which sharply marked pre-war Serbian architectural history. Following in Millet's footsteps, whose greatest merit lies exactly in bolstering the myth of Serbian national authenticity in architecture, Deroko first identified the styles of church buildings in medieval Serbia as quintessentially Serbian, and interpreted them according to the dialectic of foreign influences/autochthonous values. Moreover, he distinguished the entire history of architecture in medieval Serbia as a peculiar adaptation of imported architectural elements and features, which he saw as a transformation from 'foreign' to 'indigenous'. 'Thus far we have generally examined what kind of influences were active on our ancient sacral architecture', he wrote in the introduction of his study, stressing that 'all these different forms, which had been transferred to our soil [sic!], were neither borrowed nor alien'. He concluded that 'our medieval architecture, in spite of its eclectic nature, retained a distinctive [national] spirit' ${ }^{49}$ More particularly, he applied an already existing theory about the tripartite influences of Byzantium, Western Europe and the 'paleo-Christian Orient' on Serbian art, ${ }^{50}$ specifying that the latter had arrived to Serbia both directly and filtered through Byzantine influences. ${ }^{51}$

What requires attention regarding the theoretical and conceptual aspects of Monumental and Decorative Architecture and his other works on the subject, is not only the continuity with Milletian views, but also certain differences. Apart from routinely referring to the Marxist understanding of historical dynamics, which was naturally missing in L'ancien art serbe, Deroko gave credence to a purportedly demotic nature of ecclesiastical architecture in medieval Serbia. Despite church dignitaries and noblemen being responsible for the construction, he argued that medieval churches and monasteries were characterised by a distinctive 'folk spirit'. Not only did the common people build these structures, but they also contributed to their conspicuous architectural expression..$^{52} \mathrm{He}$ thought that medieval art and architecture had arisen from the character of the people and that this character would be comprehended as a link between society and culture. This demotic discourse on art, which originated within 
pre-war historiography and its cult of national authenticity, was not uncommon in socialist Yugoslavia. ${ }^{53}$ The same could be said of the interpretive pattern attempting to correlate artistic and political development, which Deroko employed while describing the interdependence of the allegedly autochthonous political life of medieval Serbia and the uniquely authentic character of its culture. This interpretation relied on a common view of medieval Serbia, seen through the lenses of an 'indigenous basis and foundation' for the development of society and culture. In this respect, Serbs stood in sharp contrast to some other Yugoslav nations like Slovenes or 'Macedonian Slavs', whose culture was undomesticated and heavily influenced by 'adopted models that had already been developed elsewhere'.${ }^{54}$ And it was exactly this contrapuntal interpretation that served as a link to an older, Milletian interpretive tradition of justifying not only the authenticity, but also the superiority of Serbian medieval architecture and its eminent status regarding its neighbours. In the ideological context of the cryptic and smoldering conflict between different Yugoslav nations that had not subsided after WWII - as well as between different ways of justifying the federalist composition of the state - Deroko's adoption of the older historical tradition was quite telling of the endurance of attitudes toward Serbian historical exceptionality. In the political context of the time, the role of historiography was simultaneously constructive and subversive because every reconsideration of the 'original territorial division [of Yugoslavia] would open Pandora's box' of national enmities and territorial disputes, according to Stevan K. Pavlowich. ${ }^{55}$

Deroko's critical attitude to the Serbian national question is explicit in the opening remarks of Monumental and Decorative Architecture, where he endeavored to outline the scope of his enquiry, accommodating it to a predominant federalist paradigm of history. 'In this book', he explained, 'we examine architecture in medieval Serbia, but as it was directly related to that of Old Zeta - today's Montenegro, as well as that of Macedonia, our project will cover these [lands], insofar as they were more closely connected with Serbian architecture, relinquishing to Macedonia and Montenegro the entire study of architecture in their countries'. ${ }^{56}$ Elsewhere in the book, he acknowledged and conceded that the 'Skopje scientific center' had capacity to conduct research on Macedonian architecture. ${ }^{57}$ His account reveals a common attitude of Yugoslav art and architectural historiography towards objects of historical research. On the one hand, architecture was studied on its own terms and contextualised according to its specific historical context. On the other, there was a federalist principle of competence, superimposed by communist elites, who seriously impinged on historiography so that 'each [Yugoslav] republic created its own national narrative of history, while avoiding meddling in other republics' affairs'. ${ }^{58}$ Such a dualistic framework of history, illustrated by the 
above quoted remark, was inherently problematic. There were a number of research problems concerned with medieval architectural monuments in the region, which transcended and challenged federalist competence, and which could not be appropriately addressed if seen in the narrow perspectives of republican-national historiographies. Thus, the seemingly simple formula for handling matters historical according to the federalist paradigm, which could be described paraphrasing the cuius regio, eius religio principle, was conflictual in its very nature. Because the boundaries of the Yugoslav nations did not coincide with those of its republics, the cuius regio, eius natio dictum was constantly challenged by the counter-principle cuius natio, eius regio. ${ }^{59}$ Consequently, the interpretation of various phenomena from the distant, prenational past (such as medieval architecture) simultaneously had to conform to the political imperatives of federalisation and maintain historical veracity. Deroko's references to the 'concern of the others', i.e. the domain of republican competence in pursuit of a republican-national architectural history actually stemmed from the federalist paradigm which represented much more than a mere principle of territorial division of the state.

Perhaps the most conspicuous example of this interpretive dualism can be seen in Deroko's book With Ancient Master Builders: Medieval Monasteries in Serbia, Montenegro and Macedonia (1967). Here, the federalisation principle is deeply rooted not only in the book's title, but in its structure too. However, the concept of split competence was at same time compromised by excluding the Macedonian and Montenegrin heritage that the nation-centred interpretive tradition considered non-Serbian. This means that the heritage which was considered Serbian (by style, historical circumstances or the national spirit) should have been left solely to Serbian scholars. He tried to justify his breach of the federalist principle of competency, given the importance of exploring the entirety of medieval 'Serbian' architecture, which obviously did not correspond with modern political boundaries. He routinely acknowledged that since Macedonia, Montenegro and Serbia 'were once united within the confines of the Serbian state', ${ }^{60}$ this obliged modern Serbian historians to deal with these territories, implicitly entrusting their cultural heritage solely to Serbian scholars. However, he gave no explanation whatsoever for excluding a medieval heritage considered to be non-Serbian from a book allegedly discussing entire medieval architecture in Macedonia, Serbia, Kosovo and Montenegro. This dual interpretive perspective, sharply marked by the simultaneous acceptance and rejection of the federalist principle of competency, engendered a tension between the condition of the past - which bespoke a cultural and ethnic unity of the 'Serbian lands'; and of the present, characterised by the republican boundaries which divided the national body and had no historical legitimacy. 
The key problem of the federalist paradigm, which greatly influenced contemporaneous historiography and shed light on Deroko's works, lay in the incongruity between the ethnic boundaries of the Yugoslav peoples and the borders of the republics. This was because, '[t]he members of a nation were not restricted to the republic in which the nationality predominated but included all those of like ethnic (or national) background, whatever part of Yugoslavia they inhabited [...]' ${ }^{61}$ Indeed, the problem was that the Serbian nation was partitioned into several constitutive republics and two autonomous provinces. The process of federalisation became more and more irrevocable, reaching its apex in the late 1960s and early 1970s. The final constitution of the Socialist Federal Republic of Yugoslavia adopted in 1974, which strengthened the sovereignty of the republics and made Yugoslavia an ethnically based 'polycentric polyarchy', ${ }^{62}$ further reinforced this tension and left many of the Serbian intelligentsia disgruntled. What was needed in this political context was the cultivation of a discourse that may 'offer a refuge from the worries of the world, as well as a structure for the spiritual and cultural unity of the nation', providing Serbian nationalists 'with the dream image of a nation emancipated and unified - emancipated spiritually and even politically'. ${ }^{63}$ Not only did ranting pleas by some politically active writers and dissidents speak of the 'substantial and historical unity of the Serbian national culture', ${ }^{64}$ but many other intellectuals coming from various different cultural fields - the visual arts and film, history writing and philosophy - encouraged the cultural imagination of a re-unified national body. Since each federal historiography's authority over territorial scope of research might have clashed with the territorial distribution of historical phenomena considered to be national, historians faced a weighty conundrum rooted in such a contradictory position. This inevitably presented a continual challenge and indirectly led to disputes over the conceptual foundations of the federalist paradigm. It was in this discursive field - situated in the context of a vague fusion of natural and historical rights that justified the Yugoslav federalist system - which prompted an intellectual and ideological ferment that both ascertained and challenged republican and national sovereignty and the relationship of the Yugoslav nations and nationalities to the republics. ${ }^{65}$

The epistemological and ideological relevance of Deroko's works on medieval architecture can only be comprehended in this wider discourse on federalisation. This explains his dual perspective articulated in Monumental and Decorative Architecture, where he simultaneously acknowledged the federalist principle of historiographical competence (i.e. each republic is responsible for the history of its own territory) and the importance of a sound historical method, which explained the past in its own terms without considering current issues 
(i.e. objects of historical research must be observed in their own context and consequently interpreted). Actually, he simultaneously accommodated and challenged the federalist principle of competence as a pattern of interpreting medieval past. By taking into account those architectural monuments from the neighboring Yugoslav federal units which were more closely connected with architectural remnants lying within the boundaries of Serbia proper, ${ }^{66}$ he superimposed the past on the present, implicitly disregarding the competence of other federal units to deal with what he otherwise called the area of their expertise. This implied, rather tacitly, that the architectural heritage of medieval Serbia 'naturally' belongs to modern-day Serbs, whose historical inheritance transcended the current (but in terms of historical legitimacy quite dubious) republican borders. According to the same argument, Macedonian and Montenegrin historians were left to carry out research of limited scope, dealing only with those architectural monuments erected prior and subsequent to the Nemanjić's rule of these territories.

In order to justify this singular framework of study, and perhaps being aware of having violated the federalist principle, Deroko explained in an almost apologetic tone that he "would present those Macedonian churches that had been built by the same nobleman responsible for the churches across Kosovo and Metohija, which for that sake belonged to the same historical, architectural and stylistic group'. However, he was explicit in declaring that his interpretive prerogatives 'did not render the entire Macedonian architecture Serbian'. ${ }^{67}$ This very sentence from the first edition of Monumental and Decorative Architecture, with which Deroko completed the Milletian section about the subdivision into three distinctive groups, was omitted from the second and third editions of the book. The change did not result only from the need to be economical with space, but as a presumable response to a more lenient attitude towards the federalist competence, which went hand in hand with the loosening of centralism in the 1960s and 1970s and brought vexation to the Serbs who remained dispersed in different parts of the country. This becomes clear if one compares a number of graphical representations in the first and second editions of the book, especially a map of 'Serbian lands' stretching across modern-day Serbia, Macedonia, Albania, Kosovo and Montenegro, parts of Greece, Dalmatia and Bulgaria. Deroko's cartographic representation of what he saw as a purely Serbian territory - he did not deliberately use the term 'medieval Serbia' - was rendered in red and stood out among otherwise black-and-white printed pages. (Fig. 3) It lacked any indication of time or period whatsoever, suggesting an ahistorical and homogeneous ethnic character of the represented territory. Here one can again appreciate the striking contrast between the national present and past, 


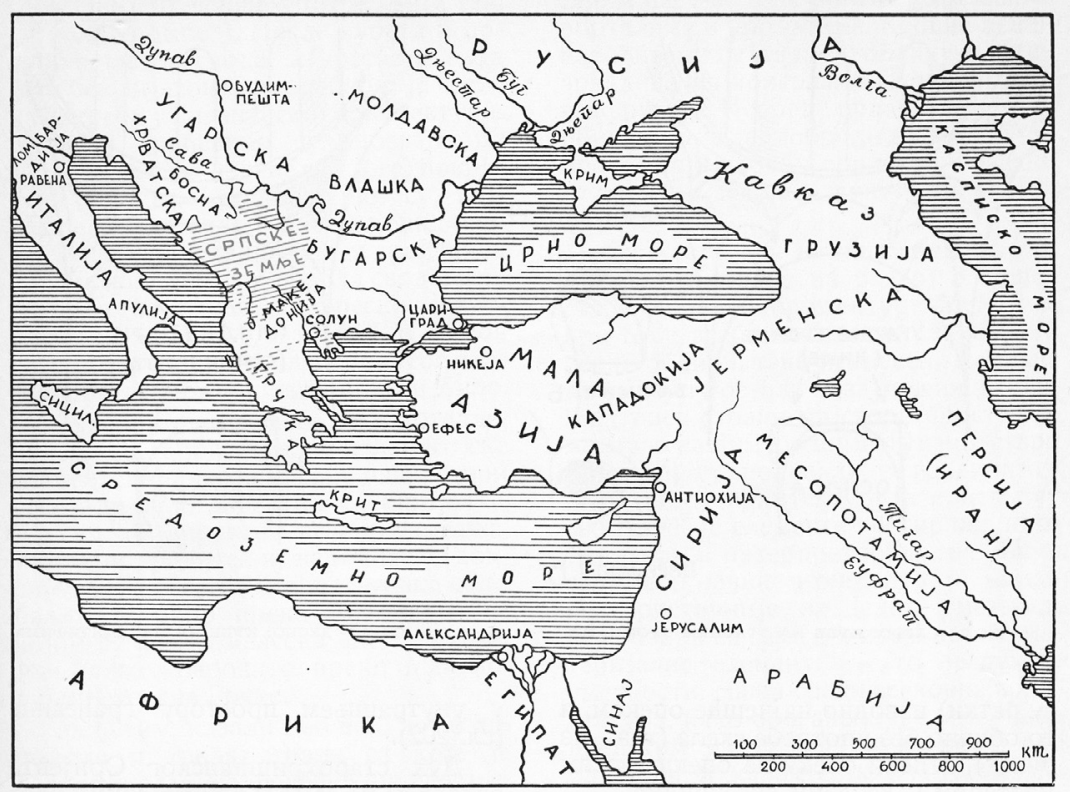

Fig. 3. A. Deroko's map of 'Serbian Lands' from 1953. (Source: Aleksandar A. Deroko, Monumentalna $i$ dekorativna arhitektura u srednjovekovnoj Srbiji (Belgrade: Naučna knjiga, 1953), 13.)

Fig. 4. A. Deroko's map of 'Serbian Lands' from 1962. (Source: Aleksandar A. Deroko, Monumentalna $i$ dekorativna arhitektura u srednjovekovnoj Srbiji (Belgrade: Naučna knjiga, 1953), 10.)

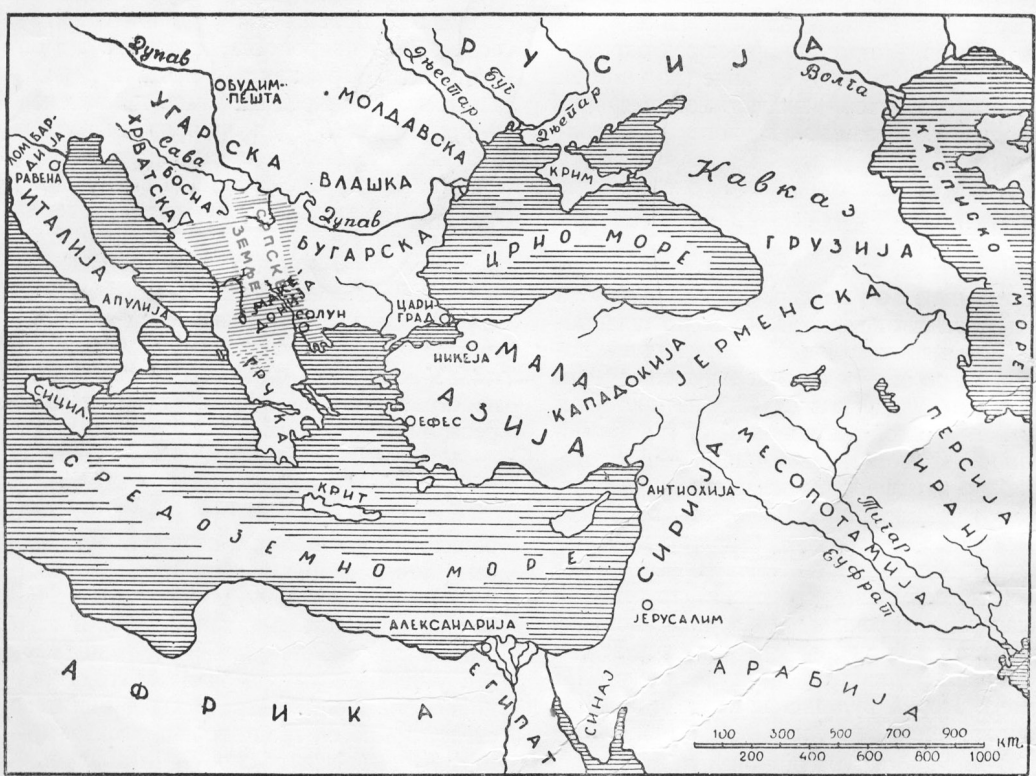


which produced a critical discourse on the relationship between nations and republics. Yet, the comparison of these maps in two editions of the book reveals much more than a vestige of nationalistic sentiment focused on 'Southern Serbia', which was how Macedonia had been traditionally called by Serbian nationalists. The maps showed two hatching patterns, composed of full and dotted lines, most likely referring to permanently and temporarily occupied 'Serbian' lands in the Balkans. On the map from 1953, Deroko presumably used dotted lines suggesting that Macedonia (along with large swathes of Albania and Greece) had been Serbian for a limited time only; or that Macedonia's ethnic identity had been uncertain. In the 1962 edition, however, the hitherto dotted-line hatched areas were shaded by full lines, with Macedonia becoming an integral, inseparable part of what Deroko called the 'Serbian lands'. (Fig. 4) Coupled with a missing sentence from the 1953 edition about the Macedonian medieval architecture not being Serbian, this graphical enlargement of the nation's historical territory represented a visual-rhetorical assertion of the extent of the national domain. This is evident not only in his encircling of the 'Serbian lands', but also in his interchangeable use of various terms like the 'architecture of Medieval Serbia' and the 'Serbian architecture'. It presupposed the unquestionably national historical identity over the territories once in the hands of Serbs which were now becoming more and more divorced from their original rulers' inheritors.

Closely connected to this point is the already noted fact that Deroko's maps referred to an unspecified period of the past, representing 'Serbian lands' in an uncontextualised and atemporal totality. In this way, the maps functioned as typical 'icons of possession' ${ }^{6}{ }^{68}$ which stood in sharp opposition to the political reality of Yugoslavia and symbolically corresponded to the nationalist ideal of political boundaries coinciding exactly with the ethnic ones. Not only did Deroko's curious maps graphically constructed the national body in history, but they also showed where the national present was in relation to its past. The importance of the territorial-historical nation-mapping in contemporaneous Yugoslav historiography is perhaps best seen in the already mentioned History of Yugoslav Peoples, published the same year as Monumental and Decorative Architecture. This book had quite a few folding maps related to early and late medieval history, featuring legend categories such as 'state boundaries' and 'capitals' which were, of course, irrelevant for the political formations in medieval Europe characterised by fluid frontiers. ${ }^{69}$ Notwithstanding the fact that the direct projection of modern political concepts on the medieval past is somewhat different from Deroko's vague strategy of nationalising historical territories, both tactics were part of the same critical discourse, implicitly questioning the historical foundations of the Yugoslav federalist paradigm. 
There is no doubt that the relevance of Deroko's historical studies to the national imagination in post-WWII Serbia far surpassed his scholarly and artistic diligence, which is still praised by many historians and laymen. Seen in the perspective of the national question in socialist Yugoslavia and its federalist conundrum of the relationship between ethnicity and territory, Monumental and Decorative Architecture in Medieval Serbia, along with other Deroko's works, reveals a conspicuous ideological stream through the Serbian national narrative of the time. In the context of constantly rising ethnic nationalisms hidden beneath the rhetoric of "brotherhood and unity", the reactivation of Millet's arguable identification of architectural styles with national identities served as a potent ideological force, which offered an alternative to the current state of the nation split along the borders of the republics. Indeed, the seemingly unorthodox coexistence of different competing political ideas, in which the ideology of Yugoslav socialism itself became an instrument in the contention between the centralist/unitarst and decentralist/distincivist camps' ${ }^{70}$ represents a necessary condition for understanding Deroko's narratives. On the one hand, his writings on medieval architecture responded to the predominant idea of an interrelated and harmonious history and the culture of South Slavs, who all sought to gain and protect national freedom in the past and create distinctively national cultures. On the other hand, there was an ideological pressure that the Yugoslav peoples should be clearly distinguished by different histories and identities, which heavily influenced his Milletian views on the local architectural history. The overlapping of the two interpretive models, which understandably caused certain anxiety, in fact problematised the cultural foundations of the Yugoslav federalism because it 'encouraged a closer association between nationality and territory'. ${ }^{71}$ In such a dynamic ideological environment, various intellectual endeavours like his historical works 'picked up what the political class had not dare to handle'. ${ }^{72}$ Hardly can one find a work of such an enduring influence in the field of architectural history which responded so keenly to the challenges that socialist Yugoslavia posed to the Serbian national question. 
On Aleksandar Deroko's life and work see: Marija Vranić-Ignjačević, Legende Beogradskog univerziteta: Aleksandar Deroko (Belgrade: Univerzitetska biblioteka, 2004); Zoran M. Jovanović, Aleksandar Deroko (Belgrade: Republički zavod za zaštitu spomenika kulture i Društvo konzervatora Srbije, 1991).

Aleksandar A. Deroko, Monumentalna i dekorativna arhitektura u srednjovekovnoj Srbiji (Belgrade: Naučna knjiga, 1953'; 1962²); Aleksandar A. Deroko, Monumentalna i dekorativna arhitektura u srednjovekovnoj Srbiji (Belgrade: Turistička štampa, 1985). On Deroko's influence as a pedagogue see: Branislav Milenković, “Aleksandar Deroko (1894-1988)", Marija Vranić-Ignjačević, Legende Beogradskog univerziteta: Aleksandar Deroko (Belgrade: Univerzitetska biblioteka, 2004), 5-7. The book's introductory chapters have different structures in the first and second edition.

Z. Jovanović, Aleksandar Deroko, 28.

Marija Vranić-Ignjačević, Legende Beogradskog univerziteta: Aleksandar Deroko, 32.

Gabriel Millet, L'ancien art serbe: les églises (Paris: E. de Boccard, 1919).

A conspicuous case in this respect was the international conference "Niš and Byzantium" held in 2006, which was dedicated to the memory and work of the 'glorious and cult name of Gabriel 
Millet', as Tsvetan Grozdanov, the then president of the Macedonian Academy of Sciences and Arts and a member of the Serbian Academy of Sciences and Arts has put it in his opening speech. See: Cvetan Grozdanov, "U slavu Gabrijela Mijea," in Niš $i$ Vizantija: zbornik radova Vol. IV, ed. M. Rakocija (Niš: Grad Niš and Prosveta, 2006), 9-16. On Millet’s operation see: Slobodan Ćurčić, "Architecture in Byzantium, Serbia and the Balkans Through the Lenses of Modern Historiography," in Serbia and Byzantium. Proceedings of the International Conference Held on 15 December 2008 at the University of Cologne, Series: Studien und Texte zur Byzantinistik Vol. 8, eds. Mabi Angar and Claudia Sode (Frankfurt am Main et al.: Peter Lang, 2013), 11-12.

S. Ćurčić, "Architecture in Byzantium, Serbia and the Balkans Through the Lenses of Modern Historiography," 12.

See more on the topic in: Aleksandar Ignjatović, U srpsko-vizantijskom kaleidoskopu: Arhitektura, nacionalizam i imperijalna imaginacija 1878-1941 (Belgrade: Orion Art i Univerzitet u Beogradu - Arhitektonski fakultet, 2016). See also: Aleksandar Ignjatović, "Byzantium's Apt Inheritors: Serbian Historiography, Nation Building and Imperial Imagination, 1882-1941," Slavonic and East European Review 94/1 (2106): 57-92.

A. Deroko, Monumentalna ${ }^{1}, 6$.

Z. Jovanović, Aleksandar Deroko, 13. On Millet's work at the École Pratique des Hautes Études see: Dubravka Preradović, "Contribution de Gabriel Millet à l'étude de l'art Serbe," Z' Epistēmonikó Synédrio 'To Ágion Óros sta chrónia tēs Apeleuthérōsēs', Phoros timēs ston Gabriel Millet / $7^{\text {th }}$ International Scientific Conference 'Mount Athos at the Years of Liberation'. Conference Proceedings (Thessaloniki: Agioritikiestia, 2013), 77-82.

On the 'unparalleled character of Millet's classification' see: Predrag N. Dragojević, Istorija umetnosti u Srbiji u prvoj polovini XX veka (Unpublished PhD thesis, Univerzitet u Beogradu Filozofski fakultet, 1996), 93.

See for example: Cyril Mango, Byzantine Architecture (New York: Rizzoli, 1985), 176.

S. Curčić, "Architecture in Byzantium, Serbia and the Balkans through the Lenses of Modern Historiography," 16.

M. Vranić-Ignjačević, Legende Beogradskog univerziteta, 24.

A. Deroko, Monumentalna ${ }^{1}$, 23. See the recent Serbian translation: Petar P. Pokriškin, Pravoslavna crkvena arhitektura XII-XVIII veka u Kraljevini Srbiji (Belgrade: Art Press, 2014 [1906]).

Miloje M. Vasić, Žiča i Lazarica: studije iz srpske umetnosti srednjega veka (Belgrade: Geca Kon, 1928); Louis Brehier, "Srpska i rumunska umetnost u srednjem veku," Starinar II (1923): 63-68. It is ironic that Miloje Vasić, in his review of Deroko's book, ascertained that it was an 'indispensable work for future architects and scholars': M. Vasić, "Nova knjiga o staroj umetnosti," Republika (29. 12. 1953). Cited after: Z. Jovanović, Aleksandar Deroko, 28 n. 89.

Aleksandar Deroko, “Đ. Bošković, Srednjovekovna umetnost u Srbiji Makedoniji (crkvena arhitektura i skulptura)," Starinar I (1950): 280.

Aleksandar Deroko, Sa starim neimarima: Srednjovekovni manastiri u Srbiji, Crnoj Gori $i$ Makedoniji (Belgrade: Turistička štampa, 1967), 24-27.

Slobodan Ćurčić, Architecture in the Balkans: From Diocletian to Süleyman the Magnificent (New Haven and London: Yale University Press, 2010), 9 n. 17. Curčić suggests that the term 'group' was probably taken from Pokriškin.

A. Deroko, Monumentalna ${ }^{1}, 23$. Yet even in this respect, he was not consistent because he defined 'the Morava Group' not only in terms of style but also considering geographical location.

Videti: S. Curčić, “Architecture in Byzantium,” 15.

Aleksandar Deroko, Spomenici arhitekture IX-XVIII veka u Jugoslaviji (Belgrade: Univerzitet u Beogradu i Građevinska knjiga, 1964). 
See: S. Ćurčić, “Architecture in Byzantium,” 16-17; Jelena Bogdanović, "Regional Developments in Late Byzantine Architecture and the Question of 'Building Schools': An Overlooked Case of the Fourteenth-Century Churches from the Region of Skopje," Byzantinoslavica. Revue internationale des études byzantines LXIX, 1-2 (2011): 219-266.

See: Z. Jovanović, Aleksandar Deroko, 6.

Jasna Dragović-Soso, 'Saviours of the Nation': Serbia's Intellectual Opposition and the Revival of Nationalism (London: Hurst \& Co., 2002), 8.

Branko Petranović, Istorija Jugoslavije 1918-1988. Vol. 3: Socijalistička Jugoslavija 1945-1988 (Belgrade: Nolit, 1988), 319.

On this particular topic see: Nenad Makuljević, "Od umetnosti nacije do umetnosti teritorije," in Jugoslavija u istorijskoj perspektivi, eds. Latinka Perović et al. (Belgrade: Helsinški odbor za ljudska prava, 2017), 426.

B. Petranović, Istorija Jugoslavije, 327.

Miroslav Krleža, "Predgovor," in Izložba srednjovjekovne umjetnosti naroda Jugoslavije (Zagreb: Umjetnički paviljon, 1951), 5.

B. Petranović, Istorija Jugoslavije, 325.

On Marxist historiography see: Q. Edward Wang and Georg G. Iggers, "Introduction," in Marxist Historiographies: A Global Perspective, eds. Q. Edward Wang and Georg G. Iggers (London: Routledge, 2016), 1-15.

A. Deroko, Monumentalna ${ }^{1}, 7-10$.

Q. Wang and G. Iggers, "Introduction," 4.

A. Deroko, Monumentalna1, 9.

See: Karl Marx, Kritika političke ekonomije (Zagreb: Naprijed, 1958 [1859]). Marx’s A Contribution to the Critique of Political Economy, 1859.

A. Deroko, Monumentalna 10.

The first and second volumes of the book were published in 1953 and 1959, while the third (and the last) one has never been published due to antagonism between different members of the editorial board which consisted of numerous historians as the republics' representatives coming from all over the country, see: Ivo Banac, "Historigraphy of the Countries of Eastern Europe: Yugoslavia," The American Historical Review 97/4 (1992): 1086.

Bogo Grafenauer, Dušan Petrović, Jaroslav Šidak (eds.), Istorija naroda Jugoslavije. Vol. 1 - Do početka XVI veka (Belgrade: Prosveta, 1953), IX.

Pamela Ballinger, "Revisiting the History of World War II," in: History in Exile: Memory and Identity at the Borders of the Balkans (Princeton: Princeton University Press, 2003), 106.

Ernst Breisach, Historiography: Ancient, Medieval and Modern (Chicago: University of Chicago Press, 2007), 352.

Ethnic minorities in Yugoslavia were officially recognised as nationalities only in 1959.

See: Aleksandar Palavestra, Kulturni konteksti arheologije (Belgrade: Univerzitet u Beogradu - Filozofski fakultet, 2011), 153-163; Zorica Kuzmanović, "Problem kulturnog identiteta u savremenoj arheološkoj praksi," Etnoantropološki problemi, 6/3 (2011): 596 (595-605); Monika Z. Milosavljević, Koncept drugosti varvarstva i varvarizacije u srpskoj arheologiji (Unpublished $\mathrm{PhD}$ thesis, Univerzitet u Beogradu - Filozofski fakultet, 2015), 104-105; Predrag Novaković, "Archaeology in the New Countries of Southeastern Europe: A Historical Perspective," in Comparative Archaeologies: A Sociological View of the Scienece of the Past, ed. Ludomir L. Lozny (Cham: Springer, 2011), 339-461; Predrag Novaković, Historija arheologije u novim zemljama Jugoistočne Evrope (Sarajevo: Univerzitet u Sarajevu, 2014). 
See: Paul Shoup, Communism and the Yugoslav National Question (New York: Columbia University Press, 1968), 115-118.

A. Deroko, Monumentalna ${ }^{1}, 319$.

See: Aleksandar Ignjatović, U srpsko-vizantijskom kaleidoskopu: Arhitektura, nacionalizam $i$ imperijalna imaginacija 1878-1941 (Belgrade: Orion Art i Univerzitet u Belgradeu-Arhitektonski fakultet, 2016), 546-602.

A. Deroko, Monumentalna ${ }^{1}, 15$.

A. Deroko, Monumentalna ${ }^{1}, 12$.

A. Deroko, Monumentalna $1,15$.

A. Deroko, Monumentalna ${ }^{1}, 8$.

See for instance: B. Grafenauer, G. Ostrogorski et al., "Jugoslovenski narodi u ranofeudalno doba", 107-302.

B. Grafenauer, G. Ostrogorski et al., "Jugoslovenski narodi u ranofeudalno doba”, 127, 130.

Stevan K. Pavlowitch, The Improbable Survivor: Yugoslavia and its Problems 1918-1988 (Columbus: Ohio State University Press, 1988), 89.

A. Deroko, Monumentalna ${ }^{1}, 5$; A. Deroko, Monumentalna ${ }^{2}$, 5. Emphasis is added by the author.

A. Deroko, Monumentalna ${ }^{1}, 23$.

Mari-Žanin Čalić, Istorija Jugoslavije u 20. veku (Belgrade: Clio, 2013), 321.

See: Stefano Bianchini, "Partitions: Categories and Destinies," in Partitions: Reshaping States and Minds, eds. Stefano Bianchini et al. (London: Routledge, 2005), 46.

A. Deroko, Sa starim neimarima: Srednjovekovni manastiri u Srbiji, Crnoj Gori i Makedoniji, 7.

P. Shoup, Communism and the Yugoslav National Question, 115.

Dennison I. Rusinow, The Yugoslav Experiment 1948-1974 (London: Hurst, 1977), 228. Cf. John R. Lampe, Yugoslavia as History: Twice there was a country (Cambridge: Cambridge University Press, 2000), 305-306.

S. Pavlowitch, The Improbable Survivor, 106-109.

Dobrica Ćosić, Stvarno i moguće (Rijeka: Otokar Keršovani, 1982), 120. This phrasing by the Serbian writer and academic Dobrica Ćosić appeared only in the early-1970s, see: J. DragovićSoso, "Saviours of the Nation," 41.

Ascertaining both natural rights of the Yugoslav peoples and historical identity of the republics, the federal constitution of 1946 provided an ambiguous policy towards national sovereignty. This conceptual conundrum was partially solved by the second Yugoslav constitution adopted in 1953, which annulled the sovereignty of the republics and introduced a new, but equally problematic concept of the nations' sovereignty, which was further sanctioned by the 1964 federal constitution.

A. Deroko, Monumentalna ${ }^{1}, 5$; A. Deroko, Monumentalna ${ }^{2}, 5$. Emphasis is added by the author.

A. Deroko, Monumentalna ${ }^{1}, 27$.

G. N. G. Clarke, "Taking Possession: The Cartouche as Cultural Text in Eighteen-Century American Maps," Word and Image: A Journal of Visual/Verbal Enquiry, 4/2 (1988): 455.

See more in: Arthur Percival Newton, "The Conception of the World in the Middle Ages," in Travel and Travellers in the Middle Ages, ed. Arthur Percival Newton (London: Routledge, 2004), 1-18. On the ideological roles of maps see more in: Denis Wood, with John Fels and John Krygier, Rethinkig the Power of Maps (New York: The Guilford Press, 2002).

I. Banac, "Historigraphy of the Countries of Eastern Europe," 1089.

S. Pavlowitch, The Improbable Survivor, 73.

S. Pavlowitch, The Improbable Survivor, 76. Cf. Wachtel, Andrew Baruch. Making a Nation, Breaking a Nation: Literature and Cultural Politics in Yugoslavia (Stanford, CA: Stanford University Press, 1998), 128-171. 
Babić, Staša. “Arheologija i etnicitet.” Etnoantropološki problemi 5/1 (2010): 137-148.

Ballinger, Pamela. History in Exile: Memory and Identity at the Borders of the Balkans. Princeton: Princeton University Press, 2003.

Banac, Ivo. "Historigraphy of the Countries of Eastern Europe: Yugoslavia." The American Historical Review 97/4 (1992): 1084-1104.

Bianchini, Stefano. "Partitions: Categories and Destinies." In Partitions: Reshaping States and Minds, edited by Stefano Bianchini et al, 40-77. London: Routledge, 2005.

Bogdanović, Jelena. "Regional Developments in Late Byzantine Architecture and the Question of 'Building Schools': An Overlooked Case of the Fourteenth-Century Churches from the Region of Skopje." Byzantinoslavica. Revue internationale des études byzantines LXIX, 1-2 (2011): 219-266.

Brehier, Louis. "Srpska i rumunska umetnost u srednjem veku.” Starinar II (1923): 63-68.

Breisach, Ernst. Historiography: Ancient, Medieval and Modern. Chicago: University of Chicago Press, 2007.

Čalić, Mari-Žanin. Istorija Jugoslavije u 20. veku. Belgrade: Clio, 2013.

Clarke, G. N. G. "Taking Possession: The Cartouche as Cultural Text in Eighteen-Century American Maps." Word and Image: A Journal of Visual/Verbal Enquiry 4/2 (1988): 455-474.

Ćosić, Dobrica. Stvarno i moguće. Rijeka: Otokar Keršovani, 1982.

Ćurčić, Slobodan. "Architecture in Byzantium, Serbia and the Balkans Through the Lenses of Modern Historiography." In Serbia and Byzantium. Proceedings of the International Conference Held on 15 December 2008 at the University of Cologne. Series: Studien und Texte zur Byzantinistik. Vol. 8, edited by Mabi Angar and Claudia Sode, 9-31. Frankfurt am Main et al.: Peter Lang, 2013.

Ćurčić, Slobodan. Architecture in the Balkans: From Diocletian to Süleyman the Magnificent. New Haven and London: Yale University Press, 2010

Deroko, Aleksandar A. Monumentalna i dekorativna arhitektura u srednjovekovnoj Srbiji. Belgrade: Naučna knjiga, $1953^{1}$.

Deroko, Aleksandar A. Monumentalna i dekorativna arhitektura u srednjovekovnoj Srbiji. Belgrade: Naučna knjiga, $1962^{2}$.

Deroko, Aleksandar A. Monumentalna i dekorativna arhitektura u srednjovekovnoj Srbiji. Belgrade: Turistička štampa, 1985).

Deroko, Aleksandar. "Đ. Bošković, Srednjovekovna umetnost u Srbiji Makedoniji (crkvena arhitektura i skulptura).” Starinar I (1950): 280.

Deroko, Aleksandar. Sa starim neimarima: Srednjovekovni manastiri u Srbiji, Crnoj Gori $i$ Makedoniji. Belgrade: Turistička štampa, 1967.

Deroko, Aleksandar. Spomenici arhitekture IX-XVIII veka u Jugoslaviji. Belgrade: Univerzitet u Beogradu and Građevinska knjiga, 1964.

Dragojević, Predrag N. "Istorija umetnosti u Srbiji u prvoj polovini XX veka." Unpublished PhD thesis, Belgrade: Univerzitet u Beogradu - Filozofski fakultet, 1996.

Dragović-Soso, Jasna. 'Saviours of the Nation': Serbia's Intellectual Opposition and the Revival of Nationalism. London: Hurst \& Co., 2002.

Grafenauer, Bogo; Ostrogorski, Georgije. et al. "Jugoslovenski narodi u ranofeudalno doba." In Istorija naroda Jugoslavije. Vol. 1 - Do početka XVI veka, edited by Bogo Grafenauer, Dušan Perović, Jaroslav Šidak, 107-302. Belgrade: Prosveta, 1953.

Grafenauer, Bogo; Petrović, Dušan and Šidak, Jaroslav (eds.). Istorija naroda Jugoslavije. Vol. 1 Do početka XVI veka. Belgrade: Prosveta, 1953. 
Grozdanov, Cvetan. "U slavu Gabrijela Mijea.” In Niš i Vizantija: zbornik radova. Vol. IV, edited by M. Rakocija, 9-16. Niš: Grad Niš and Prosveta, 2006.

Ignjatović, Aleksandar. “Byzantium’s Apt Inheritors: Serbian Historiography, Nation Building and Imperial Imagination, 1882-1941.” Slavonic and East European Review 94/1 (2016): 57-92.

Ignjatović, Aleksandar. U srpsko-vizantijskom kaleidoskopu: Arhitektura, nacionalizam i imperijalna imaginacija 1878-1941. Belgrade: Orion Art and Univerzitet u Beogradu Arhitektonski fakultet, 2016).

Jovanović, Zoran M. Aleksandar Deroko. Belgrade: Republički zavod za zaštitu spomenika kulture and Društvo konzervatora Srbije, 1991.

Krleža, Miroslav. "Predgovor.” In Izložba srednjovjekovne umjetnosti naroda Jugoslavije. Zagreb: Umjetnički paviljon, 1951.

Kuzmanović, Zorica. "Problem kulturnog identiteta u savremenoj arheološkoj praksi." Etnoantropološki problemi 6/3 (2011): 595-605.

Lampe, John R. Yugoslavia as History: Twice there was a country. Cambridge: Cambridge University Press, 2000.

Makuljević, Nenad. "Od umetnosti nacije do umetnosti teritorije." In Jugoslavija u istorijskoj perspektivi, edited by Latinka Perović et al, 414-433. Belgrade: Helsinški odbor za ljudska prava, 2017.

Mango, Cyril. Byzantine Architecture. New York: Rizzoli, 1985.

Marx, Karl. Kritika političke ekonomije. Zagreb: Naprijed, 1958 [1859].

Milenković, Branislav. “Aleksandar Deroko (1894-1988)." In Legende Beogradskog univerziteta: Aleksandar Deroko, edited by Marija Vranić-Ignjačević, 5-7. Belgrade: Univerzitetska biblioteka, 2004.

Millet, Gabriel. L’ancien art serbe: les églises. Paris: E. de Boccard, 1919.

Milosavljević, Monika Z. "Koncept drugosti varvarstva i varvarizacije u srpskoj arheologiji." Unpublished doctoral thesis, Univerzitet u Beogradu - Filozofski fakultet, 2015.

Newton, Arthur Percival. "The Conception of the World in the Middle Ages." In Travel and Travellers in the Middle Ages, edited by Arthur Percival Newton, 1-18. London: Routledge, 2004.

Novaković, Predrag. "Archaeology in the New Countries of Southeastern Europe: A Historical Perspective." In Comparative Archaeologies: A Sociological View of the Scienece of the Past, edited by Ludomir L. Lozny, 339-461. Cham: Springer, 2011.

Novaković, Predrag. Historija arheologije u novim zemljama Jugoistočne Evrope. Sarajevo: Univerzitet u Sarajevu, 2014.

Palavestra, Aleksandar. Kulturni konteksti arheologije. Belgrade: Univerzitet u Beogradu Filozofski fakultet, 2011.

Pavlowitch, Stevan K. The Improbable Survivor: Yugoslavia and its Problems 1918-1988. Columbus: Ohio State University Press, 1988.

Petranović, Branko. Istorija Jugoslavije 1918-1988. Vol. 3. - Socijalistička Jugoslavija 1945-1988. Belgrade: Nolit, 1988.

Pokriškin, Petar P. Pravoslavna crkvena arhitektura XII-XVIII veka u Kraljevini Srbiji. Belgrade: Art Press, 2014 [1906].

Preradović, Dubravka. “Contribution de Gabriel Millet à l'étude de l'art Serbe.” In Z’Epistēmonikó Synédrio 'To Ágion Óros sta chrónia tēs Apeleuthérōsēs', Phoros timēs ston Gabriel Millet / 7th International Scientific Conference 'Mount Athos at the Years of Liberation'. Conference Proceedings, 77-82. Salonika: Agioritikiestia, 2013.

Rusinow, Dennison I. The Yugoslav Experiment 1948-1974. London: Hurst, 1977. 
Shoup, Paul. Communism and the Yugoslav National Question. New York: Columbia University Press, 1968.

Vasić, Miloje M. Žiča i Lazarica: studije iz srpske umetnosti srednjega veka. Belgrade: Geca Kon, 1928.

Vasić, Miloje. "Nova knjiga o staroj umetnosti.” Republika (29. 12. 1953).

Vranić-Ignjačević, Marija. Legende Beogradskog univerziteta: Aleksandar Deroko. Belgrade: Univerzitetska biblioteka, 2004.

Wachtel, Andrew Baruch. Making a Nation, Breaking a Nation: Literature and Cultural Politics in Yugoslavia. Stanford, CA: Stanford University Press, 1998.

Wang, Q. Edward and Iggers, Georg G. "Introduction.” In Marxist Historiographies: A Global Perspective, edited by Q. Edward Wang and Georg G. Iggers. 1-15. London: Routledge, 2016.

Wood, Denis; Fels, John and Krygier, John. Rethinkig the Power of Maps. New York: The Guilford Press, 2002. 